\title{
Research Competencies of Medical University Teachers: Evaluation, Perception, and Perspective
}

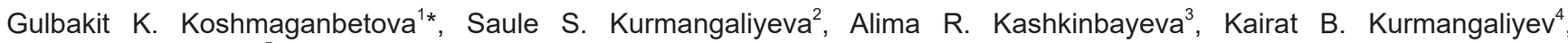 \\ Nurgul U. Alekenova ${ }^{5}$ \\ ${ }^{1}$ Family Medicine and Primary Care Research Center, West Kazakhstan Marat Ospanov Medical University, Aktobe, Kazakhstan; \\ ${ }^{2}$ Department of Microbiology, West Kazakhstan Marat Ospanov Medical University, Aktobe, Kazakhstan; ${ }^{3}$ Center for Continuing \\ Professional Development, West Kazakhstan Marat Ospanov Medical University, Aktobe, Kazakhstan; ${ }^{4}$ Department of \\ Strategic Development and Quality Management, West Kazakhstan Marat Ospanov Medical University, Aktobe, Kazakhstan; \\ ${ }^{5}$ Department of Academic Work, West Kazakhstan Marat Ospanov Medical University, Aktobe, Kazakhstan
}

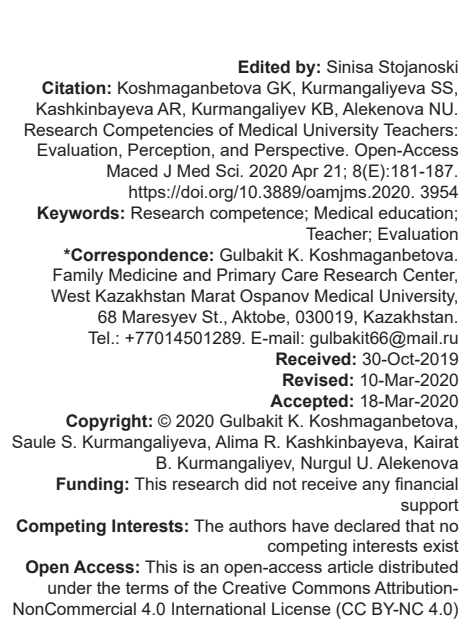

\section{Abstract}

BACKGROUND: Research competence is one of the important competencies of a medical teacher.

AIM: The aim of study was to evaluate the research competencies teachers $(n=90)$ by online questionnaires.

METHODS: The questionnaire assessed transferable research skills, research-specific skills (research design, data collection, and analysis), research experience, attitude, and motivation to conduct research.

RESULTS: About $55 \%$ of respondents are fully aware of the research activities at their university. Higher rates in transferred skills were established: Teamwork (average score 8/10: 55.5\%), and ability to collect information (average score $8 / 10: 47.9 \%$ ). Low general skills (project management and time management) are $15.6 \%$ and $12.2 \%$ of the teachers surveyed. Low indicators of specific research skills of biostatistics (average score 1/4$18.9 \%$ ) and article submission (average score 1/4-13.2\%) were revealed. Competence of male teachers is higher than that of women in their transmitted information collection skills $(Z=2.6, p=0.008)$, evaluation of information $(Z=2.4, p=0.015)$, and problem solving $(Z=2.3, p=0.02)$. Specific research skills did not depend on the gende and affiliation to the department. Most teachers understood the term "research" as "the process of obtaining new knowledge," and "experimenting and/or testing hypotheses." Skills require improvement: Biostatistics skills, design definition, preparation of abstracts, and articles. Most respondents showed high motivation (71.1\%) to conduct research.

CONCLUSION: The research competencies of university teachers' need to be improved. It is necessary to focus on the integration of special research skills in programs on all levels of education.

\section{Introduction}

The processes of reform and modernization of higher medical education increase the importance of scientific research at the university. This is due to the fact that in the context of reducing state funding in Kazakhstan, universities need to look for additional sources, including receiving grants for research activities. In addition, indicators of the effectiveness of the university are based on quantitative and qualitative indicators of productivity and effectiveness of scientific research conducted at the university. New paradigms in teaching and learning in higher education put the student at the center of the process, and the teacher as an intermediary in a new educational and research environment based on the wider demand for specific research skills and potential [1], [2], [3], [4] [5], [6], [7].

The activities of a medical teacher require scientific skills such as data interpretation, problem-solving, experimental design, scientific writing, oral communication, teamwork and critical analysis of primary literature, and the integration of these skills into curricula. Despite the high evaluation of medical faculty students' acquisition of skills of the scientific process, most teachers do not devote enough time to impart research skills [8], [9]. According to the literature, today there is disagreement among teachers about the unity of research and teaching as a necessary condition for a good education [10], [11]. There is a tendency to integrate a scientific and scientifically based approach into basic medical education [12]. This once again underlines the need for a general definition of the role of a scientist [13]. Accordingly, research competence is one of the important competencies of a medical teacher. Unfortunately, for various reasons, most teachers do not have the ability to develop and implement research skills in the educational process [14]. 


\section{Aim}

The aim of the research was to evaluate the perception, and perspectives of research competencies teachers at West Kazakhstan Marat Ospanov Medical University, Aktobe, Kazakhstan.

\section{Methods}

\section{Study design}

The cross-sectional study, approved by the Local Ethics Committee of the University (Protocol No. 2 dated January 30, 2018), was conducted in 2018 among the teachers at the West Kazakhstan Marat Ospanov Medical University.

\section{Participants}

The sample size was calculated by the formula 1 for cross-sectional studies:

$$
\frac{n=N Z^{2} \times p(1-p)}{d^{2}(N-1)+Z^{2} p(1-p)}
$$

where $N=200 ; Z=1.96 ; p=0.2 ; d=0.05$

From the general list of university teachers by a simple random sample using the generation of random numbers, 111 people were selected. The survey participants were informed in advance about the purpose of the study and agreed to participate in the study. In an informed consent, it was explained that participation is voluntary, and the answers are confidential and will be used exclusively for research purposes. It was suggested to answer the online questionnaire questions through the automated information systsem "Sirius" in the period from March to April 2018. The response to the questionnaire was $79.6 \%$ (90 teachers).

\section{Measures}

The research tool was based on a questionnaire developed at the University of Reading by the Center for Excellence in Teaching and Learning Applied Student Research Skills (CETL-AURS) (http://www.reading. ac.uk/cetl-aurs/) [15]. The choice of the questionnaire was due to the lack of standardized tools for assessing the participation of medical educators in research work, and CETL-AURS most consistent with the stated objectives of our study. The questionnaire was modified to include: Specific questions to determine the current state of research competencies, questions about the participation and experience of past research, and the availability of publications. The final adjustment was made after a preliminary survey with a small group of teachers. The questionnaire consisted of four sections: Demographic data, your research skills, your understanding of research, research at the university, and your interests. The respondents were required to self-assess the level of general and specific skills on a 10-point Likert-type scale (from 8 to 10 - good, from 5 to 7 - satisfactory, and from 1 to 4 - unsatisfactory). The motivation to participate in the research from 16 points was estimated on a 7-point scale from -3 (low) to +3 (high motivation). Possible barriers and attitudes to participation in research work were identified by analyzing the relevant literature in the PubMed database.

In the present study, the Cronbach's alpha coefficient for "general skills" scales was 0.94; for "research skills" - 0.93; the motivation scale had a Cronbach's alpha coefficient of 0.84 , which indicates good internal consistency.

\section{Data}

Statistical data analysis was performed by the program Statistica 10 (Stat Soft. USA). Frequencies and shares were used to describe qualitative data (gender, department, and academic degree). The data on the level of competence of teachers were grouped into lower and higher levels using two equal cutoff points. A visual check of the data was carried out using histograms and $\mathrm{Q}-\mathrm{Q}$ sections and tested according to the KolmogorovSmirnov statistics. Mann-Whitney $U$ and KruskalWallis tests were used to study the differences between perceived levels of competence with transferable and research-specific skills. For research data, on the levels of motivation for research used tests ANOVA. The relationship between general and specific research skills, the presence of a scientific degree, age, and the experience was identified using Spearman correlation. Categorical data on teachers' awareness of research activities at the university were tested using Pearson's Chisquare $\left(\chi^{2}\right)$. The criteria values corresponding to $p<0.05$ were considered statistically significant. Qualitative data on the understanding of teachers of the term "research" were analyzed using a thematic approach and methods of constant comparison of the authors.

\section{Results}

\section{Demographic characteristics}

In our study we involved 90 teachers. The response rate of teachers/assistants without a degree was $50 \%(n=45)$, masters $30 \%(n=27)$, and Ph.D. $20 \%(n=18)$. The demographic characteristics of the participants are presented in Table 1 . Women made up $86.7 \%$, more than half $(63.4 \%)$ of the total group were teachers aged 25-45 years. Demographic data by sex and age are representative of our teaching community. 
Table 1: Demographic characteristics of teachers

\begin{tabular}{|c|c|c|}
\hline Teacher characteristics & Number of respondents & $\%$ \\
\hline \multicolumn{3}{|l|}{ Gender } \\
\hline Female & 78 & 86.7 \\
\hline Male & 12 & 13.3 \\
\hline \multicolumn{3}{|l|}{ Age groups (years) } \\
\hline $25-29$ & 14 & 15.6 \\
\hline $30-35$ & 20 & 22.2 \\
\hline $36-40$ & 9 & 10 \\
\hline $41-45$ & 14 & 15.6 \\
\hline $46-50$ & 11 & 12.2 \\
\hline $51-55$ & 4 & 4.4 \\
\hline \multicolumn{3}{|l|}{ Status } \\
\hline Teacher/assistant without a degree & 45 & 50 \\
\hline Master & 27 & 30 \\
\hline Ph.D. & 18 & 19.9 \\
\hline \multicolumn{3}{|l|}{ Department } \\
\hline Preclinical & 32 & 35.6 \\
\hline Clinical & 58 & 64.4 \\
\hline \multicolumn{3}{|l|}{ Scientific and teaching experience (years) } \\
\hline Up to 10 years & 58 & 64.5 \\
\hline $11-20$ years & 27 & 30 \\
\hline Over 21 years & 5 & 5.6 \\
\hline \multicolumn{3}{|l|}{ Experience in research over the past 5 years } \\
\hline Head & 6 & 6.7 \\
\hline Executor & 84 & 93.3 \\
\hline \multicolumn{3}{|l|}{ The presence of articles in publications } \\
\hline Members of the Web of Science, Scopus & 20 & 22.2 \\
\hline Recommended by the ministry of education & 29 & 32.2 \\
\hline In leading peer-reviewed journals in the commonwealth countries & 25 & 27.8 \\
\hline \multicolumn{3}{|l|}{ Research awareness at West Kazakhstan Marat Ospanov Medical University } \\
\hline Not fully aware & 2 & 2.2 \\
\hline Mostly do not know & 9 & 10 \\
\hline To some extent & 30 & 33.3 \\
\hline Good & 46 & 51.1 \\
\hline Very good & 3 & 3.3 \\
\hline \multicolumn{3}{|l|}{ Understanding of the term "research" } \\
\hline Getting new knowledge & 42 & 46.7 \\
\hline Experimental/test hypotheses & 43 & 47.8 \\
\hline Collection and evaluation of information & 5 & 5.5 \\
\hline \multicolumn{3}{|l|}{ The importance of the prospects for the practical use of scientific results } \\
\hline Yes, this is a defining moment for applying a scientifically oriented approach in the educational process & 46 & 51 \\
\hline Yes, it matters what is purely scientific interest & 21 & 23.3 \\
\hline Yes, but this is not the main thing, first of all, I am interested in the scientific result itself & 18 & 20 \\
\hline No, I am not interested in the practical use of my scientific results & 5 & 5.6 \\
\hline \multicolumn{3}{|l|}{ Barriers to participation in research projects } \\
\hline Insufficient funding & 34 & 37.8 \\
\hline Late notification of terms and conditions & 16 & 17.8 \\
\hline Language barrier & 29 & 32.2 \\
\hline Level of own scientific competence & 29 & 32.2 \\
\hline The workload with other activities & 51 & 56.7 \\
\hline Lack of initiative and the expectation that the head should do it & 15 & 16.7 \\
\hline \multicolumn{3}{|l|}{ Barriers to participation in international conferences } \\
\hline Lack of information about ongoing conferences & 3 & 3.3 \\
\hline Lack of funding & 38 & 42.2 \\
\hline Low level of language proficiency & 16 & 17.8 \\
\hline Level of own research & 35 & 38.9 \\
\hline Lack of initiative and the expectation that it should be done by the head & 4 & 4.4 \\
\hline No barriers & 7 & 7.8 \\
\hline
\end{tabular}

From Table 1, it can be seen that teachers of clinical departments made up of $64.4 \%$ of the entire sample, teachers of preclinical departments made up of $35.6 \%$. This corresponds to the distribution in the general population of university teachers. Sixty-four percent of teachers had a work experience at a medical university for up to 10 years. Forty-five percent of respondents are poorly informed or not at all aware of research conducted at the university. When classifying categorical statements of teachers, it has been established that the majority of respondents understand the term "research" as "the process of obtaining new knowledge," and "experimenting and/or testing hypotheses." With the skills requiring improvement, most of the teachers indicated: Biostatistics skills, research design, and abstract writing. According to the majority, barriers to participation in research projects are congestion with other activities, insufficient funding, the level of their own scientific competencies, and language barriers. Half of all teachers interviewed, assessing the importance of the prospects for the practical use of scientific results, agree that this is a defining moment for the application of a science-oriented approach in the educational process. All teachers have experience in scientific research, including medical, of which $6.7 \%$ have the experience of a research manager. Eighty-two percent of teachers have publications and, accordingly, skills of writing articles and abstracts, but of which only $22.2 \%$ of respondents have publications in Web of Science and Scopus.

\section{Common transferable and specific research skills of interviewed teachers}

Competences in the common transferable and specific research skills of the university teachers surveyed are given in Table 2. Most of the teachers report higher indicators in the transferred skills such as teamwork (an average score of $8 / 10$ was $55.5 \%$ ) and the ability to collect information (an average score of $8 / 10: 47.9 \%)$. General skills, such as project 
Table 2: Descriptive statistics of transferable and research skills of interviewed teachers

\begin{tabular}{|c|c|c|c|c|c|c|c|c|c|c|c|c|c|c|}
\hline \multirow[t]{3}{*}{$\overline{\text { Skills }}$} & \multirow{3}{*}{$\begin{array}{l}\text { Total } \\
\text { Total } \\
(n=90) \\
\text { Me }(\bar{x})\end{array}$} & \multicolumn{3}{|c|}{ Total of competence \% } & \multicolumn{2}{|l|}{ Gender } & \multicolumn{2}{|c|}{ Department } & \multicolumn{3}{|c|}{ Experience/years } & \multicolumn{3}{|l|}{ Scientific status } \\
\hline & & $\begin{array}{l}\text { Low } \% \\
1-4\end{array}$ & $\begin{array}{l}\text { Average } \\
\% 5-7\end{array}$ & $\begin{array}{l}\text { High \% } \\
8-10\end{array}$ & $\begin{array}{l}\text { Male } \\
(n=12)\end{array}$ & $\begin{array}{l}\text { Female } \\
(n=78)\end{array}$ & $\begin{array}{l}\text { Clinical } \\
(n=58)\end{array}$ & $\begin{array}{l}\text { Preclinical } \\
(n=32)\end{array}$ & $\begin{array}{l}0-10 \\
(n=58)\end{array}$ & $\begin{array}{l}11-20 \\
(\mathrm{n}=27)\end{array}$ & $\begin{array}{l}\text { Over } 20 \\
(n=5)\end{array}$ & $\begin{array}{l}\text { Without a } \\
\text { degree }(n=45)\end{array}$ & $\begin{array}{l}\text { Master } \\
(\mathrm{n}=27)\end{array}$ & $\begin{array}{l}\text { Ph.D. } \\
(n=18)\end{array}$ \\
\hline & & & & & $\operatorname{Me}(\bar{x})$ & $\operatorname{Me}(\bar{x})$ & $\operatorname{Me}(\bar{x})$ & $\operatorname{Me}(\bar{x})$ & $\operatorname{Me}(\bar{x})$ & $\operatorname{Me}(\bar{x})$ & $\operatorname{Me}(\bar{x})$ & $\operatorname{Me}(\bar{x})$ & $\operatorname{Me}(\bar{x})$ & $\operatorname{Me}(\bar{x})$ \\
\hline Information gathering & $7.0(7.0)$ & 3.3 & 48.9 & 47.9 & $8.0(8.1)$ & $7.0(6.9)$ & $7(7.1)$ & $7.0(6.8)$ & $6.8(7.0)$ & $7.4(8.0)$ & $7.2(8.0)$ & $7(6.9)$ & $6.7(7.0)$ & $7.9(8.0)$ \\
\hline Information evaluation & $7.0(6.8)$ & 5.5 & 50.1 & 44.4 & $8.0(7.9)$ & $7.0(6.7)$ & $7(6.9)$ & $7.0(6.7)$ & $6.8(7.0)$ & $7.1(7.0)$ & $6.2(8.0)$ & $7(6.7)$ & $6.4(7.0)$ & $7.8(8.0)$ \\
\hline Numeracy & $7.0(6.7)$ & 7.8 & 51.1 & 41.1 & $8.0(7.5)$ & $7.0(6.6)$ & $7(6.8)$ & $6.0(6.5)$ & $6.6(7.0)$ & $7.2(8.0)$ & $5.8(7.0)$ & $6(6.6)$ & $6.3(7.0)$ & $7.6(8.0)$ \\
\hline Teamwork & $8.0(7.2)$ & 5.5 & 39 & 55.5 & $8.0(7.4)$ & $8.0(7.2)$ & $8(7.3)$ & $7.5(7.1)$ & $7.2(7.0)$ & $7.4(8.0)$ & $6.6(8.0)$ & $7(7.2)$ & $6.9(8.0)$ & $7.6(8.0)$ \\
\hline Work independently & $7.0(6.9)$ & 7.7 & 51.1 & 42.2 & $8.0(7.3)$ & $7.0(6.8)$ & $7(6.9)$ & $7.0(6.8)$ & $6.8(7.0)$ & $7.2(8.0)$ & $6.4(8.0)$ & $7(6.7)$ & $6.7(7.0)$ & $7.7(8.0)$ \\
\hline Project management & $6.0(6.1)$ & 15.6 & 68.8 & 27.7 & $7.0(6.8)$ & $6.0(6.0)$ & $7(6.1)$ & $6.0(6.2)$ & $6.1(6.0)$ & $6.6(7.0)$ & $3.8(5.0)$ & $6(6.1)$ & $5.6(6.0)$ & $7.1(7.0)$ \\
\hline Time management & $7.0(6.4)$ & 12.2 & 54.5 & 33.3 & $8.0(7.2)$ & $6.5(6.3)$ & $7(6.4)$ & $6.0(6.30)$ & $6.2(6.0)$ & $6.8(7.0)$ & $6.0(7.0)$ & $6(6.3)$ & $6.0(6.0)$ & $7.3(7.5)$ \\
\hline Problem-solving & $7.0(6.6)$ & 10 & 52.2 & 38.8 & $8.0(7.4)$ & $7.0(6.5)$ & $7(6.7)$ & $6.0(6.5)$ & $6.5(7.0)$ & $6.9(7.0)$ & $5.6(7.0)$ & $6(6.5)$ & $6.3(7.0)$ & $7.4(8.0)$ \\
\hline \multicolumn{15}{|l|}{ Specific research skills } \\
\hline Designing a study & $6.5(7.0)$ & 10 & 55.5 & 35.5 & $7.2(8.0)$ & $6.4(7.0)$ & $6.6(7.0)$ & $6.2(6.0)$ & $6.5(7.0)$ & $6.7(7.0)$ & $5.2(5.0)$ & $6.5(7.0)$ & $5.9(6.0)$ & $7.4(8.0)$ \\
\hline Study sampling & $6.2(6.0)$ & 12.2 & 65.5 & 23.3 & $6.7(7.0)$ & $6.2(6.0)$ & $6.3(7.0)$ & $6.1(6.0)$ & $6.1(6.0)$ & $6.5(7.0)$ & $6.2(7.0)$ & $6.3(6.0)$ & $5.9(6.0)$ & $6.7(7.0)$ \\
\hline Participant recruitment & $6.3(6.0)$ & 8.8 & 63.5 & 27.7 & $6.5(7.0)$ & $6.3(6.0)$ & $6.5(7.0)$ & $6.1(6.0)$ & $6.4(6.0)$ & $6.3(7.0)$ & $6.2(7.0)$ & $6.2(6.0)$ & $6.1(6.0)$ & $7.0(7.0)$ \\
\hline Biostatistics skills & $6.0(6.0)$ & 18.9 & 60 & 21.1 & $6.6(6.5)$ & $5.9(6.0)$ & $6.0(6.0)$ & $5.9(6.0)$ & $5.9(6.0)$ & $6.1(6.0)$ & $6.0(6.0)$ & $6.0(6.0)$ & $5.6(6.0)$ & $6.4(6.5)$ \\
\hline Paper preparation & $6.7(7.0)$ & 6.6 & 51.2 & 42.2 & $7.3(8.0)$ & $6.6(7.0)$ & $6.8(7.0)$ & $6.5(7.0)$ & $6.5(7.0)$ & $7.3(8.0)$ & $6.4(7.0)$ & $6.4(6.0)$ & $6.5(7.0)$ & $7.5(8.0)$ \\
\hline Paper presenting & $6.4(7.0)$ & 13.3 & 53.4 & 33.3 & $6.8(7.0)$ & $6.3(6.5)$ & $6.5(7.0)$ & $6.1(6.0)$ & $6.3(6.0)$ & $6.6(7.0)$ & $6.2(6.0)$ & $6.1(6.0)$ & $6.2(6.0)$ & $7.2(8.0)$ \\
\hline
\end{tabular}

management and time management $(15.6 \%$ and $12.2 \%$ ), received low marks. The lowest (average grade $1 / 4-18.9 \%)$ skills in biostatistics and paper presenting were assessed (average score 1/4-13.2\%).

Specific research skills in our study did not depend on the gender and affiliation to the department. However, in transferred skills, such as information gathering skills $(Z=2.6, p=0.008)$, information evaluation skills $(Z=2.4, p=0.015)$, and problemsolving skills $(Z=2.3, p=0.02)$ teachers men proved to be significantly more competent than women. A small but statistically significant correlation was found between the skills of independent work (work independently) $(r=0.21, p<0.05)$, and information evaluation skills $(r=0.22, p<0.05)$, and scientific status. It is established that the skills of biostatistics weakly negatively correlate with age $(r=-0.24, p<0.05)$. The paper preparation skills are weakly positively correlated with the experience $(r=0.24, p<0.05)$ and scientific status $(r=0.22, p<0.05)$.

\section{Motivation for research}

Sixty-one percent of teachers surveyed are interested in scientific research. We have classified self-assessment of the level of motivation of teachers to conduct research in the field of low, medium, and high rates, using equal cutoff points (Table 3 ). More than two-thirds of the respondents showed high motivation $(71.1 \%)$, almost a quarter $(23.4 \%)$ moderate, and only $5.45 \%$ low motivation.

We revealed an inverse statistically significant relationship between motivation to participate in an independent research project at the university $(r=-0.32, p<0.05)$, in the conferences Web of Science, and Scopus $(r=-0.4, p<0.05)$, in global clinical health research $(r=-0.3, p<0.05)$, and to facilitate access to travel to other universities/countries $(r=-0.3$, $p<0.05)$ and age group. There is also a weak positive correlation $(r=0.27, p<0.05)$ between the presence of an academic degree and the motivation to participate in scientific research due to interest in the scientific discipline. A slight inverse correlation is established between scientific status and lack of interest in scientific research $(r=-0.3, p<0.05)$. There were no significant differences in motivation between groups of teachers based on gender, year of work, and membership in the department.

\section{Perception of research}

Qualitative analysis of teachers' answers, divided into three groups, in the sense of the term "scientific research," as well as verbal examples of the understanding of the term "scientific research" is given in Table 4.

\section{Discussion}

The study showed that more than half of the teachers surveyed reported an interest in a career, including medical research. Teachers with higher perceived competence in the field of research are more motivated to conduct research. In their understanding of the study, respondents focused on obtaining new knowledge, testing hypotheses, and conducting experiments. The identified obstacles to participation in research projects are consistent with the results of a study conducted in Pakistan among junior university teachers [16]. As for research skills, teachers with an academic/academic degree have a higher level of transferable skills (independent work and information evaluation skills) as compared to teachers who do not have degrees. This is consistent with the study by Koivula et al. (2011), where it was found that teachers with a doctoral degree demonstrated greater acquisition and dissemination of knowledge in their studies [17].

On detailed examination, our research revealed that respondent teachers with a master's degree have lower specific research competencies (although statistically insignificant) than teachers with 
Table 3: Descriptive statistics of research motivation

\begin{tabular}{|c|c|c|c|}
\hline Statements & $\begin{array}{l}\text { Low } \\
\text { (I do not agree-3-1) }\end{array}$ & $\begin{array}{l}\text { Average } \\
\text { (Neutral 0) }\end{array}$ & $\begin{array}{l}\text { High } \\
(\text { ( agree1-3) }\end{array}$ \\
\hline I will participate in research because of & $n=4$ & $n=16$ & $n=70$ \\
\hline interest in scientific discipline & $(4.4 \%)$ & $(17.8 \%)$ & $(78.2 \%)$ \\
\hline I will participate in research to facilitate & $\mathrm{n}=11$ & $n=13$ & $n=66$ \\
\hline further career growth & $(12.2 \%)$ & $(14.4 \%)$ & $(73.4 \%)$ \\
\hline My adequate scientific knowledge and & $\mathrm{n}=1$ & $\mathrm{n}=12$ & $\mathrm{n}=77$ \\
\hline $\begin{array}{l}\text { skills promotes participation in future } \\
\text { research activities }\end{array}$ & $(1.1 \%)$ & $(13.3 \%)$ & $(85.5 \%)$ \\
\hline I will participate in research activities & $n=3$ & $n=19$ & $n=68$ \\
\hline $\begin{array}{l}\text { throughout medical education } \\
\text { will participate in an independent }\end{array}$ & $\begin{array}{l}(3.3 \%) \\
n=4\end{array}$ & $\begin{array}{l}(21.1 \%) \\
n=21\end{array}$ & $\begin{array}{l}(75.6 \%) \\
n=65\end{array}$ \\
\hline research project at the university & $(4.4 \%)$ & $(23.3 \%)$ & $(72.2 \%)$ \\
\hline I plan to have authorship (sole or joint) & $\begin{array}{l}n=2 \\
(2.2 \%)\end{array}$ & $\begin{array}{l}\mathrm{n}=20 \\
(22.2 \%)\end{array}$ & $\begin{array}{l}n=68 \\
(75.6 \%)\end{array}$ \\
\hline $\begin{array}{l}\text { Web of Science and Scopus } \\
\text { I plan to have authorship (sole or }\end{array}$ & $\mathrm{n}=6$ & $\mathrm{n}=27$ & $n=57$ \\
\hline $\begin{array}{l}\text { joint) of the reviewed oral or poster } \\
\text { presentation in the Web of Science } \\
\text { conference and Scopus }\end{array}$ & $(6.6 \%)$ & $(30 \%)$ & $(63.3 \%)$ \\
\hline $\begin{array}{l}\text { I plan to have authorship (sole or } \\
\text { joint) of a peer-reviewed publication in } \\
\text { Kazakhstan and the Commonwealth } \\
\text { countries }\end{array}$ & $\begin{array}{l}n=1 \\
(1.1 \%)\end{array}$ & $\begin{array}{l}n=16 \\
(17.8 \%)\end{array}$ & $\begin{array}{l}n=73 \\
(81.2 \%)\end{array}$ \\
\hline $\begin{array}{l}\text { I plan to have authorship (sole or } \\
\text { joint) of the reviewed oral or poster } \\
\text { presentation in Kazakhstan and the } \\
\text { Commonwealth countries }\end{array}$ & $\begin{array}{l}n=4 \\
(4.4 \%)\end{array}$ & $\begin{array}{l}n=20 \\
(22.2 \%)\end{array}$ & $\begin{array}{l}n=66 \\
(73.3 \%)\end{array}$ \\
\hline I plan to have global experience in & $n=8$ & $n=31$ & $\mathrm{n}=51$ \\
\hline clinical health research & (8.8) & $(34.4 \%)$ & $(56.7 \%)$ \\
\hline I will participate in research studies & $\mathrm{n}=12$ & $n=26$ & $\mathrm{n}=52$ \\
\hline $\begin{array}{l}\text { to facilitate access to travel to other } \\
\text { universities/countries }\end{array}$ & $(13.4 \%)$ & $(28.9 \%)$ & $(57.7 \%)$ \\
\hline I will participate in research to ease the & $n=3$ & $n=15$ & $n=72$ \\
\hline & $(3.3 \%)$ & $(16.7 \%)$ & $(80.1 \%)$ \\
\hline \multirow[t]{2}{*}{ I am not interested in research at all } & $n=57$ & $n=16$ & $n=17$ \\
\hline & $(63.3 \%)$ & $(17.8 \%)$ & $(18.9 \%)$ \\
\hline
\end{tabular}

a degree of Ph.D. and without a degree. Our findings are in conflict with the study in which the masters had high self-esteem [14]. This can be explained by the fact that holders of a master's degree from our university are more critical to their own research competence.

Table 4: Understanding of the term "research" and verbal examples

\begin{tabular}{|c|c|}
\hline Theme & Verbal examples \\
\hline $\begin{array}{l}\text { Getting new } \\
\text { knowledge }(n=42)\end{array}$ & $\begin{array}{l}\text { "Scientific research - the process of studying, conceptualizing } \\
\text { and testing the theory associated with the acquisition of scientific } \\
\text { knowledge" ( } 47 \text { years old, male, the experience of } 12 \text { years) } \\
\text { "Scientific research is the process of studying and/or obtaining } \\
\text { new knowledge based on scientific assumptions and } \\
\text { experimentally verifying data" ( } 36 \text { years old, female, } 8 \text { years' } \\
\text { experience) } \\
\text { "Kind of cognitive activity, the process of obtaining new } \\
\text { knowledge" ( } 45 \text { years old, female, } 10 \text { years' experience) } \\
\text { "Scientific research is a research using scientific methods, an } \\
\text { evidence-based database for obtaining new knowledge and } \\
\text { having practical significance" ( } 42 \text { years, female, } 12 \text { years' } \\
\text { experience) }\end{array}$ \\
\hline $\begin{array}{l}\text { Experimental/test } \\
\text { hypotheses }(n=43)\end{array}$ & $\begin{array}{l}\text { "Research is a scientifically sound, articulated concept of a good } \\
\text { idea, experiment, or other methods." ( } 40 \text { years old, female, } \\
\text { experience of } 16 \text { years) } \\
\text { "The process of studying, testing hypotheses, theories" ( } 27 \\
\text { years old, female, } 1 \text {-year experience) }\end{array}$ \\
\hline $\begin{array}{l}\text { Information gathering } \\
\text { and evaluation }(n=5)\end{array}$ & $\begin{array}{l}\text { "Study, the results (positive or negative) of which, by } \\
\text { comparison, analysis, and evaluation, are used in practice } \\
\text { for the benefit of the person" ( } 55 \text { years old, female, } 25 \text { years' } \\
\text { experience) } \\
\text { "Scientific research is characterized by systematicity: the } \\
\text { research process itself and its results are brought into the } \\
\text { system, and its results; it has strict evidence and consistent } \\
\text { justification of the generalizations and conclusions made" ( } 30 \\
\text { years old, female, } 2 \text { years' experience) }\end{array}$ \\
\hline
\end{tabular}

The competence of male teachers in the transfer of skills was higher than that of women. Whereas specific research skills do not depend on gender, belonging to a department, but depend on age. With age, teachers show low biostatistics skills. The skills of preparing abstracts/articles (Paper preparation) depend on experience and scientific status. Our data are consistent with the results of a systematic review in which the most common factors affecting the competence are the teaching position, experience in health care, research activities, age, academic degree, and the type of organization in which they work [18].

Most teachers are motivated to participate in research, as they agree with the statement that they intend to participate in research in the future. Furthermore, respondents indicated a moderate or high level of motivation for research. Only a small number of teachers $(18.9 \%)$ show no interest in participating in research, as in the Saudi Arabian study [19].

An analysis of the motivation for research has shown that the younger the teachers, the more motivated they are to participate in an independent research project at the university, in the Web of Science conferences, Scopus, and in global clinical research in the field of public health. This is consistent with the results of Stvilia et al. (2018), where junior researchers were more involved in research than senior researchers [20]. It can be assumed that the need for self-actualization is the motive for research activities. This is confirmed by an example of an understanding of the term "scientific research" of a young female doctoral student, with a work experience of 2 years: "Scientific research is an integral part of scientific activity. Scientific research can be done both collectively and independently. Regular scientific research provides tremendous opportunities for manifestation and self-development."

However, two-thirds of the respondents are highly motivated due to the intention to participate in research for purely strategic reasons, i.e., to support career growth and the possibility of travel to other countries. In this case, the younger the teachers, the greater this motivation. Their answers do not correspond to the true desire for research.

Teachers who do not yet have a scientific status are not interested in scientific research. We did not found significant differences in motivation between groups of teachers based on gender, year of work, and membership in the department. Teachers, who have a degree, plan to participate in research with an interest in a scientific discipline. Our data are contrasted with the findings in a study in which the presence of a medical degree does not necessarily lead to the fact that its owners are active researchers [21]. Another study showed that teaching and research efforts are not related [22].

It is disturbing that many teachers do not fully understand the importance of the prospects for the practical use of scientific results. In addition, some of the teachers interviewed do not know about research activities in our university, although on the university website in the "Science" section and through the information portal, used at the university, provides complete information on the research conducted at 
the university. Perhaps the lack of a close relationship between research competence and research motivation are due to a lack of understanding of the concept of translational research, as well as due to the lack of awareness of research activities carried out at the university.

\section{Conclusions}

It is necessary to focus on the integration of special research skills in educational programs at all levels of education because the specific research skills obtained are not static and require constant improvement. Lifelong learning is fundamental to the future. This study showed that the research competencies of biostatistics of medical teachers at our university require improvement. We must focus our efforts on presenting the concept of translational research for educators who view research as an activity that is separated from patient contact and the learning process. One of the mechanisms to achieve this is the active involvement of students, undergraduates, doctoral students, and young teachers in research projects. It is necessary to make efforts to increase awareness of research and increase motivation for the participation of teachers and students of our university.

\section{Limitations}

This study has several limitations. First, our conclusions are based on self-assessments of teachers from the same medical university and, therefore, the results may be biased (overestimation and/or underestimation). A comparison with objective measures, such as student research results (written and verbal reviews), would help confirm our findings. Second, the questionnaire used in our study, although piloted and modified, is not formally standardized for teachers. Third, this study was conducted on a relatively small sample, which may affect the generalizability of the study. However, it can be argued that the sample was sufficiently representative of medical teachers.

\section{Acknowledgment}

We would like to thank our medical teachers at West Kazakhstan Marat Ospanov Medical University for participating in this study.

\section{References}

1. Forrest CB, Chesley FD Jr., Tregear ML, Mistry KB Development of the learning health system researcher core competencies. Health Serv Res. 2018;53(4):2615-32. https://doi. org/10.1111/1475-6773.12751

\section{PMid:28777456}

2. Nowell L, Hayden KA, Berenson C, Kenny N, Chick N, Emery C. Professional learning and development of postdoctoral scholars: A scoping review protocol. Syst Rev. 2018;7(1):224 https://doi.org/10.1186/s13643-018-0892-5

3. Knight SE, Van Wyk JM, Mahomed S. Teaching research: A programme to develop research capacity in undergraduate medical students at the University of KwaZuluNatal, South Africa. BMC Med Educ. 2016;16:61. https://doi. org/10.1186/s12909-016-0567-7

PMid:26879830

4. Sato BK, Kadandale P, He W, Murata PM, Latif Y, Warschauer M Practice makes pretty good: Assessment of primary literature reading abilities across multiple large-enrollment biology laboratory courses. CBE Life Sci Educ. 2014;13(4):677-86. https://doi.org/10.1187/cbe.14-02-0025 PMid:25452490

5. Cabral AP, Huet I. Research in higher education: The role of teachıng and student learnıng. Proc Soc Behav Sci. 2011;29:91 972017. https://doi.org/10.1016/j.sbspro.2011.11.211

6. Hubbard KE, Dunbar SD. Perceptions of scientific research literature and strategies for reading papers depend on academic career stage. PLoS One. 2017;12(12):e0189753. https://doi. org/10.1371/journal.pone. 0189753

7. Tight M. Examining the research/teaching nexus. Eur J High Educ. 2016;6(4):293-311. https://doi.org/10.1080/2156823 5.2016 .1224674

8. Coil D, Wenderoth MP, Cunningham M, Dirks C. Teaching the process of science: Faculty perceptions and an effective methodology. CBE Life Sci Educ. 2010;9(4):524-35. https://doi. org/10.1187/cbe.10-01-0005

PMid:21123699

9. Marsh TL, Guenther MF, Raimondi SL. When do students "learn-to-comprehend" scientific sources? Evaluation of a critical skill in undergraduates progressing through a science major. J Microbiol Biol Educ. 2015;16(1):13-20. https://doi. org/10.1128/jmbe.v16i1.828

10. Ifenthaler $D$, Gosper M. Research-based learning: Connecting research and instruction. In: Gosper M, Ifenthaler D, editors. Curriculum Models for the $21^{\text {st }}$ Century. New York: Springer; 2014. p. 73-89. https://doi.org/10.1007/978-1-4614-7366-4_5

11. VujaklijaA, Hren D, SambunjakD, Vodopivecl, IvanisA, MarusićA, et al. Can teaching research methodology influence students attitude toward science? Cohort study and nonrandomised trial in a single medical school J Investig Med. 2010;58(2):282-86. https://doi.org/10.2310/jim.0b013e3181cb42d9

12. Ratte A, Drees $S$, Schmidt-Ott $T$. The importance of scientific competencies in German medical curricula the student perspective. BMC Med Educ. 2018;18(1):146. https://doi. org/10.1186/s12909-018-1257-4

PMid:29921261

13. Hautz SC, Hautz WE, Keller N, Feufel MA, Spies C. The scholar role in the national competence based catalogues of learning objectives for undergraduate medical education (NKLM) compared to other international frameworks. Ger Med Sci. 2015;13:Doc20. https://doi.org/10.3109/0142159x.2015.1012490

14. Coplen AE, Klausner CP, Taichman LS. Status of current dental hygiene faculty and perceptions of important qualifications for future faculty. J Dent Hyg. 2011;85(1):57-66. 


\section{PMid:21396264}

15. Burgoyne LN, O'Flynn S, Boylan GB. Undergraduate medical research: The student perspective. Med Educ Online. 2010;15:10. https://doi.org/10.3402/meo.v15i0.5212

PMid:20844608

16. Badakhshan A, Arab M, Rashidian A, Mehrdad N, Zendehdel K Priority-setting in health research in Iran: A qualitative study on barriers and facilitators. Health Res Pol Syst. 2018;16(1):57. https://doi.org/10.1186/s12961-018-0313-1

PMid:29966530

17. Koivula M, Tarkka MT, Simonen M, Katajisto J, Salminen L. Research utilisation among nursing teachers in Finland: A national survey. Nurse Educ Today. 2011;31(1):24-30. https://doi.org/10.1016/j.nedt.2010.03.008 PMid:20605663

18. Mikkonen K, Ojala T, Sjögren T, Piirainen A, Koskinen C, Koskinen M, et al. Competence areas of health science teachers a systematic review of quantitative studies. Nurse Educ Today. 2018;70:77-86. https://doi.org/10.1016/j.nedt.2018.08.017
PMid:30170152

19. Abu-Zaid A, Alnajjar A. Female second-year undergraduate medical students' attitudes towards research at the college of medicine, Alfaisal University: A Saudi Arabian perspective. Perspect Med Educ. 2014;3(1):50-5. https://doi.org/10.1007/ s40037-013-0093-9

PMid:24288125

20. Stvilia B, Wu S, Lee DJ. Researchers' participation in and motivations for engaging with research information management systems. PLoS One. 2014;13(2):e0193459. https://doi. org/10.1371/journal.pone.0193459

PMid:29474438

21. Andriole DA, Whelan AJ, Jeffe DB. Characteristics and career intentions of the emerging MD/PhD workforce. J Am Med Assoc. 2008;300(10):1165-73. https://doi.org/10.1001/ jama.300.10.1165

22. Hassna LO, Raza S. An assessment of the relationship between the faculty performance in teaching, scholarly endeavor, and service at Qatar University. Res High Educ J. 2011;1:1-18. 